\title{
PENGARUH RATA-RATA LAMA SEKOLAH DAN PENGANGGURAN TERBUKA TERHADAP KEMISKINAN
}

\author{
Stepanie Ayu Pradipta \\ Program Studi Pendidikan Ekonomi, Fakultas Ekonomi, Universitas Negeri Surabaya \\ email: stepaniepradipta16080554056@mhs.unesa.ac.id \\ Retno Mustika Dewi \\ Program Studi Pendidikan Ekonomi, Fakultas Ekonomi, Universitas Negeri Surabaya \\ email: retnomustika@unesa.ac.id
}

\begin{abstract}
Abstrak
Data statistik BPS Provinsi Banten menunjukkan bahwa persentase penduduk miskin pada tahun 2011-2015 mengalami kemiskinan yang tidak merata yaitu tingkat kemiskinan yang jauh berbeda pada setiap kabupaten atau kota di Provinsi Banten. Penelitian mempunyai tujuan menganalisis pengaruh parsial maupun simultan Rata-Rata Lama Sekolah dan Pengangguran Terbuka terhadap Kemiskinan di Provinsi Banten. Jenis penelitian ini adalah penelitian kuantitatif asosiatif dan teknik analisis berupa analisis data panel dengan model fixed effect serta data yang digunakan merupakan data sekunder. Hasil penelitian menunjukkan secara parsial (1) Tidak terdapat pengaruh Rata-Rata Lama Sekolah terhadap Kemiskinan di Provinsi Banten, (2) Terdapat pengaruh signifikan Pengangguran Terbuka terhadap Kemiskinan di Provinsi Banten, sedangkan secara simultan (3) Terdapat pengaruh signifikan Rata-Rata Lama Sekolah dan Pengangguran Terbuka terhadap kemiskinan di Provinsi Banten. Saran yang dilakukan adalah memperhatikan pendidikan nonformal karena pendidikan nonformal juga dapat meningkatkan pekerja yang produktif serta pengoptimalan Koperasi dan UMKM karena terbukti dapat bertahan dalam masa krisis serta memberikan kontribusi pada perekonomian negara. Koperasi disini juga harus memberikan sentuhan baru dengan gaya lebih modern agar dapat menyeimbangkan dengan perkembangan zaman saat ini.
\end{abstract}

Kata Kunci : Rata-Rata Lama Sekolah, Pengangguran Terbuka dan Kemiskinan

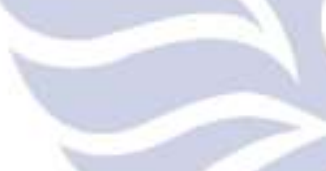

Abstract

Statistical Data of BPS Banten showed that the percentage of poor people in 2011-2015 experienced uneven poverty, which is much different poverty rate in every district or city in Banten province. This research aims to analyse both the partial and simultaneous influences Mean Years School and Open Unemployment to Poverty in Banten Province. This type of research is associative quantitative and analysis technique in the form of analysis of data panel with fixed effect model and data used is secondary data. The results of the study show partially (1) There is no influence on Mean Years School tp Poverty in Banten Province, (2) There is a significant influence on Open Unemployment to Poverty in Banten Province, while simultaneously (3) There are significant influence on Mean Years School and Open Unemployment to Poverty in Banten Province. The advice is to pay attention to informal education because non-formal education can also improve the productive workers and the optimisation of cooperatives and UMKM because it is proven to survive during crisis and contribute to the country's economy. Koperasi here must also give a new touch with a more modern style to be able to balance with the development of the current era.

Keywords : Mean Years School, Open Unemployment and Poverty. 


\section{PENDAHULUAN}

Kemiskinan merupakan suatu kondisi kekurangan yang dialami individu yang berdampak langsung terhadap kesejahteraan hidupnya. Menurut Vincent (2009), masalah kemiskinan terus menerus terjadi baik negara maju dan negara berkembang serta telah menjadi masalah yang saling berkaitan, sehingga dalam mengatasinya memerlukan cara yang tepat dan berkelanjutan. Berdasarkan data World Bank (2015) dalam daftar negara dengan persentase penduduk miskin paling besar di dunia, kemiskinan di Indonesia mencapai $15 \%$ dan menduduki peringkat ke sembilan setelah India. Tidak hanya menjadi masalah nasional, kemiskinan ini juga merambat ke setiap daerah di Indonesia, salah satunya yakni Provinsi Banten.

Persentase kemiskinan di Provinsi Banten pada tahun 2019 menurut data BPS mengalami penurunan yang jauh yaitu 5,09\% dibandingkan tahun-tahun sebelumnya. Oleh sebab itu, tingkat kemiskinan secara nasional di Provinsi Banten jika dilihat dari jumlah penduduk miskin masih lebih kecil apabila dibandingkan oleh provinsi yang terdapat di Indonesia, terutama dengan provinsi di Pulau Jawa tetapi meskipun kemiskinan di Provinsi Banten cukup rendah, data statistik BPS Provinsi Banten menunjukkan bahwa persentase penduduk miskin di Provinsi Banten masih terjadi ketidakmerataan kemiskinan setiap tahunnya yaitu tingkat kemiskinan yang jauh berbeda pada setiap kab/kota di Provinsi Banten. Hal ini menunjukkan masih belum stabilnya pergerakan jumlah kemiskinan Provinsi Banten.

Pada 5 tahun terakhir (2011-2015) kemiskinan di Provinsi Banten mengalami ketidakmerataan di setiap kabupaten atau kota, di mana persentase penduduk miskin tertinggi terdapat pada Kabupaten Pandeglang dan posisi kedua terdapat pada Kabupaten Lebak dibandingkan Kota Tangerang Selatan dan Kota Cilegon yang mana persentase penduduk miskinnya merupakan terendah. Menurut Badan Pusat Statistik, kemiskinan di Provinsi Banten tahun 2012 mencapai 5,71\% yaitu berada peringkat ke 5 terendah dari 33 provinsi lainnya di Indonesia. Kemiskinan di Provinsi Banten tahun 2013 meningkat menjadi 5,89\%, ini dapat dialami karena pemerintah menaikkan harga BBM pada bulan Juli 2013 yang akhirnya menyebabkan inflasi dan meningkatnya kemiskinan.

Menurut Solihin (2014), ada 3 faktor terbesar yang menjadi penyebab kemiskinan di Provinsi Banten. Pertama, rendahnya tingkat pendidikan. Kemiskinan di Banten didorong oleh rendahnya pendidikan serta tingginya tingkat pengangguran. Tingginya tingkat pengangguran terjadi pada wilayah industri yaitu Cilegon, Kabupaten maupun Kota Tangerang, ini menjadi bukti adanya ketidakcocokan antara ketersediaan sumber daya manusia dengan kebutuhan industri, selain itu yang juga ikut mendorong kemiskinan tersebut adalah penurunan kontribusi sektor pertanian dipedesaan, dimana rata-rata tenaga kerja dalam sektor pertanian di desa memiliki tingkat pendidikan yang rendah, sedangkan didaerah Selatan Banten, seperti Pandeglang dan Lebak tidak adanya pertumbuhan industri yang disebabkan terbatasnya akses dan kurangnya perhatian terhadap infrastruktur dari pemda ataupun kab/kota.

Kedua, inflasi. Kemiskinan di Indonesia berkaitan dengan inflasi. Berdasarkan daerah, inflasi paling tinggi terdapat di daerah Selatan Banten yaitu 16,5\% di Pandeglang, dan 15,10\% di Lebak, sedangkan paling rendah yaitu Kota Tangerang 12,84\%. Ketiga, terbatasnya sumber daya alam dan kebiasaan penduduk yang belum mengedepankan produktivitas dan daya saing.

Dari tinjauan diatas dapat diketahui bahwa faktor penyebab kemiskinan yang terjadi di Provinsi Banten diantaranya adalah pendidikan, pengangguran, inflasi dan terbatasnya sumber daya alam dan kebiasaan penduduk yang belum mengedepankan produktivitas dan daya saing. Faktor penyebab kemiskinan yang diteliti pada penelitian adalah pendidikan dan pengangguran karena berdasarkan data BPS, inflasi di Provinsi Banten cenderung stabil. Selain itu berdasarkan penelitian Kurniawan (2018) menyebutkan beberapa penyebab meningkatnya dan menurunnya kemiskinan yaitu pendidikan dan pengangguran.

Terdapat 4 program yang dilakukan pemerintah dalam menekan angka kemiskinan, yaitu Program pertama adalah Program Perlindungan Sosial Berbasis Keluarga, yang terdiri dari Jaminan Sosial Rakyat Banten Bersatu, Jaminan Kesehatan Daerah, Biaya Operasional Beras untuk Masyarakat Miskin, Beasiswa dari Gubernur, dan Biaya Operasional Sekolah daerah. Kedua, Program Pemberdayaan Masyarakat Berbasis Komunitas seperti: Program Pembangunan Perdesaan Terpadu, Gerakan Pembangunan Rakyat Banten Bersatu, Dan Gerakan Masyarakat Pertanian Terpadu. Ketiga, Program Pemberdayaan Ekonomi Kerakyatan Berbasis UMKM-K, seperti Kelompok Usaha Bersama, Kube Jaminan Sosial Rakyat Banten Bersatu, dan Jaminan Kredit Daerah. Keempat, Program Serba Murah Bagi Masyarakat Miskin dan Pemberdayaan Tenaga Kerja seperti: Bedah Kampung, Bedah Rumah, dan Listrik Desa. Kondisi perekonomian di Provinsi Banten pada tahun 2014 dengan adanya program ini semakin membaik, namun peningkatan kemiskinan terjadi pada tahun 2015 yang disebabkan tidak stabilnya perekonomian serta semakin meningkatnya kedalaman kemiskinan dan keparahan kemiskinan.

Salah satu faktor mempengaruhi kemiskinan adalah pendidikan. Pendidikan adalah pelopor 
pembangunan dalam negara. Menurut Mankiw (2012), pendidikan merupakan bentuk investasi individu, di mana jika semakin tinggi pendidikan, maka kesejahteraan suatu individu akan meningkat dan hal ini juga akan mempengaruhi jangka panjang kesejahteraan ekonomi suatu negara. Hasil yang sama juga dikemukakan pada penelitian Pramesti \& Bendesa (2016) memiliki pengaruh terhadap kemiskinan dimana kenaikan pendidikan akan menurunkan kemiskinan. Tetapi disatu sisi menurut penelitian Niswati (2014), tidak adanya pengaruh rata-rata lama sekolah terhadap kemiskinan disebabkan sektor yang berperan besar di penelitiannya adalah sektor perdagangan, hotel, restoran dan pertanian sehingga tidak terlalu membutuhkan pekerja dengan pendidikan tinggi. Peneliti memilih indikator Rata-Rata Lama Sekolah (RLS) dalam pendidikan, karena menurut BPS (2019), rata-rata lama sekolah berfungsi dalam mengetahui mutu pendidikan penduduk suatu daerah.

Kondisi pendidikan berdasarkan rata-rata lama sekolah tahun 2011-2015 di Provinsi Banten masih dibawah 9 tahun. Ini tidak sesuai dengan UU RI No. 20 (2003) Sisdiknas pasal 6 ayat 1 di mana penduduk yang berusia 7-15 tahun wajib belajar selama 9 tahun. Jika dilihat rata-rata lama sekolah berdasarkan data publikasi BPS di setiap daerah juga terdapat perbedaan yang signifikan, khususnya Kabupaten Lebak, Pandeglang dan Serang. Rata-rata lama sekolah penduduk kabupaten tersebut hanya mencapai 6 tahun lamanya, ini membuktikan belum meratanya pendidikan di kab/kota Provinsi Banten.

Faktor lainnya mempengaruhi kemiskinan adalah pengangguran. Efek buruk dari pengangguran menurut Sukirno (2004), adalah berkurangnya penghasilan yang berefek terhadap pengurangan kesejahteraan yang sudah dicapai individu. Berkurangnya kesejahteraan yang disebabkan karena menganggur, akan menyebabkan peningkatan peluang untuk terjebak dalam kemiskinan. Hasil penelitian Seran (2017) juga menyatakan pergerakan kemiskinan mengikuti pengangguran. Maksudnya, saat terjadinya kenaikan angka pengangguran, secara otomatis angka kemiskinan mengalami peningkatan.

Indikator yang digunakan ialah Tingkat Pengangguran Terbuka (TPT) karena indikator utama yang sering dipakai pemerintah untuk mengukur keberhasilan kinerjanya pada bidang tenaga kerja secara khusus pengangguran melalui tingkat pengangguran terbuka (TPT), di mana TPT adalah perbandingan total yang tidak bekerja terhadap total angkatan kerja. Pengangguran terbuka Provinsi Banten juga mengalami fluktuatif setiap tahunnya dimana pengangguran terbuka terbanyak terjadi pada tahun 2011 berkisar 11-14\%.
Rumusan masalah penelitian ini ialah (1) Adakah pengaruh rata-rata lama sekolah terhadap kemiskinan di Provinsi Banten?, (2) Adakah pengaruh pengangguran terbuka terhadap kemiskinan di Provinsi Banten?, (3) Adakah pengaruh rata-rata lama sekolah dan pengangguran terbuka terhadap kemiskinan di Provinsi Banten?

\section{METODE}

Jenis penelitian yang digunakan ialah kuantitatif asosiatif. Menurut Sugiyono (2014), asosiatif mempunyai tujuan mengetahui pengaruh dua variabel atau lebih. Tujuan dalam penelitian adalah mencari pengaruh variabel bebas kepada variabel terikat, yaitu pengaruh Rata-Rata Lama Sekolah dan Pengangguran Terbuka terhadap Kemiskinan di Provinsi Banten. Data yang digunakan ialah data sekunder. Menurut Sugiyono (2014) data sekunder merupakan data yang sudah tersedia dan peneliti tidak perlu mengumpulkan sendiri. Data sekunder penelitian ini berasal dari Badan Pusat Statistik dan BPS Provinsi Banten tahun 2011-2015. Populasi penelitian ini yaitu seluruh data Pendidikan, Pengangguran dan Kemiskinan tahun 2011-2015 di Provinsi Banten dengan sampel yang digunakan yakni semua anggota populasi yaitu Rata-Rata Lama Sekolah, Pengangguran Terbuka dan Kemiskinan tahun 2011-2015 di Provinsi Banten.

Teknik analisis yang digunakan ialah teknik analisis regresi data panel. Menurut Basuki (2015) regresi data panel adalah penggabungan data runtut waktu dan data silang dengan metode estimasi model yaitu model common effect, fixed effect dan random effect. Dalam memilih model yang benar, terdapat beberapa pengujian ialah uji chow, hausman dan lagrange multiplier. Uji lagrange multiplier digunakan jika model yang terseleksi dalam uji chow yaitu fixed effect dan model yang terseleksi dalam uji hausman yaitu random effect. jika pada uji chow dan hausman yang terseleksi adalah model fixed effect, maka tidak perlu dilakukan uji lagrange multiplier. setelah mengetahui model yang benar, maka tahap berikutnya yaitu uji hipotesis, yaitu : (1) Uji Koefisien Determinasi (R2), (2) Uji F, (3) uji T.

\section{HASIL DAN PEMBAHASAN Deskripsi Data}

Tabel 1.1. Persentase Penduduk Miskin Menurut Kabupaten/Kota Provinsi Banten Tahun 2011-2015

\begin{tabular}{|l|r|r|r|r|r|}
\hline Kab/Kota & $\mathbf{2 0 1 1}$ & $\mathbf{2 0 1 2}$ & $\mathbf{2 0 1 3}$ & $\mathbf{2 0 1 4}$ & $\mathbf{2 0 1 5}$ \\
\hline $\begin{array}{l}\text { Kab } \\
\text { Pandeglang }\end{array}$ & 9,8 & 9,28 & 10,25 & 9,5 & 10,43 \\
\hline Kab. Lebak & 9,2 & 8,63 & 9,5 & 9,17 & 9,97 \\
\hline $\begin{array}{l}\text { Kab } \\
\text { Tangerang }\end{array}$ & 6,42 & 5,71 & 5,78 & 5,26 & 5,71 \\
\hline Kab. Serang & 5,63 & 5,28 & 5,02 & 4,87 & 5,09 \\
\hline
\end{tabular}




\begin{tabular}{|l|r|r|r|r|r|}
\hline $\begin{array}{l}\text { Kota } \\
\text { Tangerang }\end{array}$ & 6,14 & 5,56 & 5,26 & 4,91 & 5,04 \\
\hline Kota Cilegon & 3,98 & 3,82 & 3,99 & 3,81 & 4,1 \\
\hline Kota Serang & 6,25 & 5,7 & 5,92 & 5,7 & 6,28 \\
\hline $\begin{array}{l}\text { Kota } \\
\text { Tangerang } \\
\text { Selatan }\end{array}$ & 1,5 & 1,33 & 1,75 & 1,68 & 1,69 \\
\hline
\end{tabular}

Sumber : BPS Provinsi Banten

Tabel 1.2. Rata-rata Lama Sekolah Menurut Kabupaten/Kota Provinsi Banten Tahun 2011-2015

\begin{tabular}{|l|r|r|r|r|r|}
\hline Kab/Kota & $\mathbf{2 0 1 1}$ & $\mathbf{2 0 1 2}$ & $\mathbf{2 0 1 3}$ & $\mathbf{2 0 1 4}$ & $\mathbf{2 0 1 5}$ \\
\hline $\begin{array}{l}\text { Kab } \\
\text { Pandeglang }\end{array}$ & 6,81 & 6,97 & 7,04 & 6,45 & 6,6 \\
\hline Kab. Lebak & 6,25 & 6,27 & 6,29 & 5,84 & 5,86 \\
\hline $\begin{array}{l}\text { Kab } \\
\text { Tangerang }\end{array}$ & 8,95 & 8,96 & 8,96 & 8,2 & 8,22 \\
\hline Kab. Serang & 7,25 & 7,36 & 7,48 & 6,69 & 6,9 \\
\hline $\begin{array}{l}\text { Kota } \\
\text { Tangerang }\end{array}$ & 10,04 & 10,07 & 10,07 & 10,2 & 10,2 \\
\hline Kota Cilegon & 9,68 & 9,72 & 9,72 & 9,66 & 9,67 \\
\hline Kota Serang & 8,01 & 8,58 & 8,59 & 8,58 & 8,59 \\
\hline $\begin{array}{l}\text { Kota } \\
\text { Tangerang } \\
\text { Selatan }\end{array}$ & 10,7 & 10,98 & 10,99 & 11,56 & 11,57 \\
\hline
\end{tabular}

Sumber : Badan Pusat Statistik

Tabel 1.3. Tingkat Pengangguran Terbuka Menurut Kabupaten/Kota Provinsi Banten Tahun 2011-2015

\begin{tabular}{|l|r|r|r|r|r|}
\hline Kab/Kota & $\mathbf{2 0 1 1}$ & $\mathbf{2 0 1 2}$ & $\mathbf{2 0 1 3}$ & $\mathbf{2 0 1 4}$ & $\mathbf{2 0 1 5}$ \\
\hline $\begin{array}{l}\text { Kab } \\
\text { Pandeglang }\end{array}$ & 11,32 & 9,3 & 12,34 & 7,03 & 10,22 \\
\hline Kab. Lebak & 12,1 & 9,07 & 7,23 & 9,57 & 10,74 \\
\hline $\begin{array}{l}\text { Kab. } \\
\text { Tangerang }\end{array}$ & 14,42 & 11,46 & 11,94 & 8,45 & 9 \\
\hline Kab. Serang & 13,29 & 12,96 & 13,69 & 14,76 & 14,8 \\
\hline $\begin{array}{l}\text { Kota } \\
\text { Tangerang }\end{array}$ & 12,89 & 8,31 & 8,62 & 7,81 & 8 \\
\hline Kota Cilegon & 13,14 & 11,31 & 7,16 & 11,83 & 12 \\
\hline Kota Serang & 13,84 & 10,8 & 11,29 & 10,03 & 9,49 \\
\hline $\begin{array}{l}\text { Kota } \\
\text { Tangerang } \\
\text { Selatan }\end{array}$ & 11,98 & 8,07 & 4,56 & 6,92 & 6,13 \\
\hline
\end{tabular}

Sumber : BPS Provinsi Banten

\section{Hasil}

Uji chow atau uji statistik $F$ adalah pengujian pemilihan statistik dalam memilih model tertepat dipakai antara model fixed effect ataukah common effect. Cara pengujiannya melihat nilai Prob.Cross-section Chi square $<0,05$, maka fixed effect merupakan yang tepat. Sebaliknya, apabila Prob.Cross-section Chi square > 0,05 , maka yang tepat adalah common effect.
Tabel 1.4. Hasil Uji Chow

\begin{tabular}{|l|l|l|l|}
\hline Effects Test & Statistic & d.f. & Prob. \\
\hline $\begin{array}{l}\text { Cross- } \\
\text { section F }\end{array}$ & 70.179632 & $(7,30)$ & 0.0000 \\
\hline $\begin{array}{l}\text { Cross- } \\
\text { section Chi- } \\
\text { square }\end{array}$ & 114.201865 & 7 & 0.0000 \\
\hline
\end{tabular}

Sumber : Hasil olah data peneliti, 2019

Diperoleh hasil Prob.Cross-section Chi square $0.0000<0,05$ dalam uji chow, maka model yang tepat dipakai adalah fixed effect.

Uji Hausman ialah uji statistik yang berguna memastikan penggunaan yang benar antara model fixed effect atau random effect. Pada Uji Hausman, apabila H1 diterima dalam tes Hausman atau p-value < 0,05 maka model yang tepat yaitu model fixed effect. Apabila H0 diterima dalam tes Hausman atau p-value > 0,05 maka model yang tepat model random effect.

Tabel 1.5. Hasil Uji Hausman

\begin{tabular}{|l|l|l|l|}
\hline $\begin{array}{l}\text { Test } \\
\text { Summary }\end{array}$ & $\begin{array}{l}\text { Chi-Sq. } \\
\text { Statistic }\end{array}$ & $\begin{array}{l}\text { Chi-Sq. } \\
\text { d.f. }\end{array}$ & Prob. \\
\hline $\begin{array}{l}\text { Cross-section } \\
\text { random }\end{array}$ & 20.602175 & 2 & 0.0000 \\
\hline
\end{tabular}

Sumber : Hasil olah data peneliti, 2019

Hasil uji hausman yang didapatkan adalah Cross-section random $0.0000<0,05$ sehingga model yang tepat dipakai ialah model fixed effect.

Koefisien determinasi dipakai dalam melihat besaran pengaruh kedua variabel independen terhadap variabel dependen, apabila hasil nilainya rendah maka variabel independen terbatas dalam menjelaskan variabel dependen. Apabila nilai koefisien determinasi mendekati 1, maka variabel independen lebih luas atau mendalam dalam menjelaskan variabel dependen.

Tabel 1.6. Hasil Uji Koefisien Determinasi (R2)

\begin{tabular}{|l|l|}
\hline Weighted Statistics & Skor \\
\hline R-squared & 0.985198 \\
\hline Adjusted R-squared & 0.980758 \\
\hline S.E. of regression & 0.355538 \\
\hline
\end{tabular}

Sumber : Hasil olah data peneliti, 2019

Uji $R$-squared diperoleh hasil sebesar 0.985198.

Oleh karena itu 98,5\% variabel independen mampu menjelaskan variabel dependen, sedangkan 1,5\% dipengaruhi variabel lain yang tidak termasuk pada penelitian.

Menurut Ghozali (2013) uji F merupakan uji hipotesis dalam mengetahui pengaruh variabel bebas secara simultan terhadap variabel terikat. Pengambilan keputusannya berdasarkan tingkat signifikansi 0,05 (5\%). 
Tabel 1.7. Hasil Uji F

\begin{tabular}{|l|l|}
\hline Weighted Statistics & Skor \\
\hline F-statistic & 221.8675 \\
\hline Prob(F-statistic) & 0.000000 \\
\hline
\end{tabular}

Sumber : Hasil olah data peneliti, 2019

Analisis uji F didapatkan hasil bahwa F-statistic $0.000000<0,05$ yang artinya Rata-Rata Lama Sekolah dan Pengangguran Terbuka terdapat pengaruh signifikan terhadap Kemiskinan.

Menurut Napitupulu, dkk (2017), uji T adalah uji hipotesis dalam mengetahui pengaruh secara parsial variabel bebas terhadap variabel terikat. Adapun variabel bebas dianggap memiliki nilai konstan apabila tingkat signifikansi 0,05 (5\%).

Tabel 1.8. Hasil Uji T

\begin{tabular}{|l|l|l|}
\hline Variable & Coefficient & Prob. \\
\hline $\begin{array}{l}\text { Rata-Rata Lama } \\
\text { Sekolah }\end{array}$ & 0.131450 & 0.5673 \\
\hline $\begin{array}{l}\text { Pengangguran } \\
\text { Terbuka }\end{array}$ & 0.065493 & 0.0390 \\
\hline
\end{tabular}

Sumber : Hasil olah data peneliti, 2019

Rata-Rata Lama Sekolah didapatkan nilai probabilitas $0.5673>0,05$ dengan koefisien regresi 0.131450 sehingga dipastikan rata-rata lama sekolah tidak terdapat pengaruh terhadap kemiskinan.

Pengangguran Terbuka didapatkan nilai probabilitas $0.0390<0,05$ dengan koefisiensi regresi 0.065493 sehingga dipastikan pengangguran terbuka berpengaruh dan signifikan terhadap variabel kemiskinan

\section{Pembahasan}

\section{Pengaruh Rata-Rata Lama Sekolah Terhadap Kemiskinan}

Pengujian dalam penelitian ini didapatkan hasil yaitu tidak terdapat pengaruh Rata-Rata Lama Sekolah terhadap Kemiskinan di Provinsi Banten, terjadi karena didapatkan nilai probabilitas $0.5673>0,05$ dengan koefisien regresi 0.131450. Rata-Rata Lama Sekolah tidak terdapat pengaruh terhadap Kemiskinan karena meskipun rata-rata lama sekolah didaerah tersebut tinggi tetapi angka kemiskinannya juga tinggi. Hal ini dibuktikan dalam data pendidikan dan kemiskinan yang menunjukkan dimana pada tahun 2011 rata-rata lama sekolah Kota Tangerang yang ditempuh cukup tinggi yakni selama 10,04 tahun, namun memiliki angka kemiskinan yang cukup besar yaitu sebesar $6,14 \%$.

Hasil penelitian tidak sesuai dengan Mankiw (2012), yang menyatakan pendidikan merupakan bentuk investasi individu, di mana jika semakin tinggi pendidikan, maka kesejahteraan suatu individu akan lebih membaik. Tidak sesuai juga dengan penelitian terdahulu Pramesti \& Bendesa (2016), dimana kenaikan pendidikan akan menurunkan kemiskinan.

\section{Pengaruh Pengangguran Terbuka Terhadap Kemiskinan}

Pengujian penelitian ini didapatkan hasil pengangguran terbuka memiliki pengaruh dan signifikan terhadap variabel kemiskinan. Pengaruh ini dibuktikan probabilitas $0.0390<0,05$ dengan koefisiensi regresi 0.065493 .

Hasil penelitian ini didukung oleh Sukirno (2004), di mana dampak negatif dari pengangguran adalah penurunan pendapatan yang diterima masyarakat yang akhirnya mengurangi tingkat kemakmuran individu. Selain itu penelitian ini didukung juga oleh Seran (2017), pergerakan kemiskinan mengikuti pengangguran. Maksudnya, saat terjadinya kenaikan angka pengangguran, secara otomatis angka kemiskinan mengalami peningkatan. Hal ini menunjukkan terjadinya pengaruh positif kemiskinan dan pengangguran. Tentunya pengangguran berdampak negatif pada negara dan daerah jika dibiarkan secara terus menerus.

\section{Pengaruh Rata-Rata Lama Sekolah dan} Pengangguran Terbuka Terhadap Kemiskinan

Uji $F$ didapatkan hasil bahwa variabel independen (X1 dan X2) signifikasi F hitungnya ialah 221.8675 dengan nilai F-statistic $0.000000<0,05$. Hasil uji F membuktikan bahwa hipotesis (H3) diterima yang artinya Rata-Rata Lama Sekolah dan Pengangguran Terbuka terdapat pengaruh simultan terhadap Kemiskinan di Provinsi Banten.

Penelitian ini didukung oleh penelitian Kurniawan (2018), dimana beberapa penyebab meningkatnya dan menurunnya kemiskinan yaitu pendidikan dan pengangguran. Juga didukung oleh pendapat Sharp, et.al dalam Kuncoro (2006), salah satu faktor kemiskinan adalah ketidaksamaan pada mutu sumber daya manusia (SDM). Rendahnya mutu SDM berakibat kepada pengetahuan dan keterampilan individu sehingga mengakibatkan produktivitas yang dihasilkan rendah yang akhirnya berdampak kepada pekerjaan individu. Rendahnya pendidikan akan mengakibatkan semakin rendah jabatan individu atau bahkan menganggur sehingga akan meningkatkan kemiskinan juga karena tidak dapat memenuhi kebutuhannya.

\section{PENUTUP}

\section{Simpulan}

Diperoleh simpulan bahwa Rata-Rata Lama Sekolah tidak terdapat pengaruh terhadap Kemiskinan di Provinsi Banten, Pengangguran Terbuka terdapat pengaruh signifikan terhadap Kemiskinan di Provinsi Banten serta secara simultan terdapat pengaruh Rata-Rata 
Lama Sekolah dan Pengangguran Terbuka terhadap Kemiskinan di Provinsi Banten.

\section{Saran}

Berdasarkan simpulan diatas, maka saran guna penelitian setelah ini adalah (1) Kondisi zaman sekarang yang semakin ketatnya dalam persaingan kerja, maka sebaiknya Dinas Pendidikan mulai memperhatikan pendidikan nonformal karena pendidikan nonformal juga mampu meningkatkan pekerja yang produktif. Oleh karena itu, sebaiknya sebagian pemberian bantuan oleh pemerintah dipakai dalam mengembangkan pendidikan nonformal, seperti memberikan pelatihan kreativitas, (2) Salah satu solusi yang dapat dioptimalkan adalah Koperasi dan UMKM karena terbukti dapat bertahan dalam masa krisis serta memberikan kontribusi tuntuk perekonomian negara. Koperasi disini juga harus memberikan sentuhan baru dengan gaya lebih modern agar dapat menyeimbangkan dengan perkembangan zaman saaat ini, (3) Dalam penelitian ini rata-rata lama sekolah tidak memiliki pengaruh terhadap kemiskinan, maka disarankan menggunakan indikator lain atau menambah jumlah tahun penelitian serta teknik analisis data lain untuk mengukur rata-rata lama sekolah.

\section{DAFTAR PUSTAKA}

Basuki, Agus Tri, and Nano Prawoto. 2015. Analisis Komposisi Pengeluaran Publik Terhadap Pertumbuhan Ekonomi Dalam Mendukung Good Governance Dalam Memasuki MEA (Studi Empiris Propinsi Di Indonesia Tahun 2010- 2014). Snema ISBN: 978-: 1-19.

BPS. 2012. Indeks Pembangunan Manusia 2010-2011. . 2013. Indeks Pembangunan Manusia 2012. 2014. Indeks Pembangunan Manusia 2013. 2015. Indeks Pembangunan Manusia 2014. 2016. Indeks Pembangunan Manusia 2015. 2019. Persentase Penduduk Miskin Menurut Kabupaten/Kota Di Provinsi Banten, 2005-2019. BPS Provinsi Banten. https://banten.bps.go.id/dynamictable/2017/04/18/1 66/persentase-penduduk-miskin-menurutkabupaten-kota-di-provinsi-banten-20052019.html.

2019. Tingkat Pengangguran Terbuka (TPT) Menurut Kabupaten/Kota Di Provinsi Banten, 2008-2019. BPS Provinsi Banten. https://banten.bps.go.id/dynamictable/2015/09/22/7 8/tingkat-pengangguran-terbuka-tpt-menurutkabupaten-kota-di-provinsi-banten-20082019.html.
Chambers, Robert. 2006. Concepts and Measures What Is Powerty? International Poverty Centre Poverty In Focus.

Ghozali, Imam. 2013. Aplikasi Analisis Multivariate Dengan Program IBM SPSS 21 Update PLS Regresi. 7th ed. Badan Penerbit Universitas Diponegoro.

Kuncoro, Mudrajad. 2006. Ekonomi Pembangunan: Teori, Masalah Dan Kebijakan. 4th ed. Yogyakarta: UPP AMP YKPN.

Kurniawan, Rizky Agung. 2018. Pengaruh Pendidikan Dan Pengangguran Terhadap Kemiskinan Di Kota Surabaya Tahun 2007 - 2016. 6(2009).

Mankiw, Gregory N. 2012. Pengantar Ekonomi Makro. Jakarta: Erlangga.

Napitupulu, Laura Amelya, R. Mafis, and M. Hasan. 2017. Pengaruh Komitmen Organisasional, Motivasi Dan Kompetensi Terhadap Kinerja Manajerial Pada Rumah Sakit Swasta Di Kota Pekenbaru. Jurnal Online Mahasiswa Bidang Ilmu Ekonomi 4(1): 338-52.

Niswati, Khurri. 2014. Faktor-Faktor Yang Mempengaruhi Kemiskinan Di Daerah Istimewa Yogyakarta Tahun 2003-2011. Eko-Regional 9(2): 82-89.

Pramesti, Nyoman Ayu Tria, and I K. G Bendesa. 2018. Pengaruh Faktor Sosial Ekonomi Terhadap Kemiskinan Di Provinsi Bali. E-Jurnal EP Unud 7(9): 1887-1917.

Seran, Sirilius. 2017. Hubungan Antara Pendidikan, Pengangguran Dan Pertumbuhan Ekonomi Dengan Kemiskinan. Jurnal Ekonomi Kuantitatif Terapan 10(2): 59-71.

Solihin, Dadang. 2014. Implementasi Kebijakan Pengentasan Kemiskinan. ed. Putra Dwitama. Jakarta: Yayasan Empat Sembilan Indonesia.

Storada, Nana. 2017. Analisa Situasi Pembangunan Manusia Kota Semarang 2016. Semarang.

Sugiyono. 2014. Metode Penelitian Pendidikan Pendekatan Kuantitatif, Kualitatif, Dan R\&D. Bandung: PT. Alfabeta.

Sukirno, Sadono. 2004. Makro Ekonomi Teori Pengantar. Jakarta: Raja Grafindo Persada.

Undang-Undang Republik Indonesia Nomor 20 Tahun 2003 Tentang Sistem Pendidikan Nasional. 2003.

Vincent. 2009. The Concept 'Poverty' towards Understanding in the Context of Developing Countries 'Poverty qua Poverty' with Some Comparative Evidence on Britain.pdf.

World Bank. 2015. Monitoring Global Development Progress. World Bank. http://pubdocs.worldbank.org/en/13009144405822 
JUPE Volume 08 Nomor 03 Tahun 2020, 109 - 115

5465/Global-Monitoring-Report-2015-MonitoringDevelopment.pdf. 